\title{
The Myth of Oxford and Black Counter-Narratives
}

\author{
Carli Coetzee $\odot$
}

\begin{abstract}
The myth of Oxford, which echoes and replicates the ideology of an unchanging world of privileged white youth, is a common trope in many films and literary works. This vision is, however, overlaid and underlaid with counter-traditions that decenter Oxford and instead insert Oxford upside down into other epistemologies, geographies, and networks. Some attempts at the transformation of elite institutions such as Oxford inadvertently serve to continue the centering of these same institutions. Coetzee argues that, instead of focusing on the histories of ascendant Black/black excellence and achievement at Oxford University, a more powerful way to relativize and decenter the institution is to document and emphasize histories and accounts of Black marginalization, failure, and disconnection.
\end{abstract}

Résumé: Le mythe d'Oxford, qui fait écho et reproduit l'idéologie d'un monde immuable de jeunes blancs privilégiés, est un trope commun à de nombreux films et œuvres littéraires. Cette vision est, toutefois, recouverte et sous-tendue de contretraditions qui décentrent Oxford et l'insèrent à l'envers dans d'autres épistémologies, géographies et réseaux. Certaines tentatives de transformation d'institutions d'élite telles qu'Oxford servent par inadvertance à poursuivre le centrage de ces mêmes institutions. Coetzee soutient qu'au lieu de se concentrer sur les histoires d'excellence et de réussite ascendantes des Noirs/noir à l'Université d'Oxford, une façon plus

African Studies Review, Volume 65, Number 2 (June 2022), pp. 288-307

Carli Coetzee is the editor of the Journal of African Cultural Studies, the founder of the Africa Journal Work Academy, and a research associate at Wits University, South Africa. She regards her editorial practice as part of an activist project that aims to change publishing patterns which favor northern-based scholars. She is the author of Written Under the Skin: Blood and Intergenerational Memory in South Africa and Accented Futures: Language Activism and the Ending of Apartheid and has edited a number of other books. E-mail: Carli.coetzee@area.ox.ac.uk

(C) The Author(s), 2022. Published by Cambridge University Press on behalf of the African Studies Association. This is an Open Access article, distributed under the terms of the Creative Commons Attribution licence (https:/ / creativecommons.org/ licenses/by/4.0/), which permits unrestricted re-use, distribution, and reproduction in any medium, provided the original work is properly cited.

doi:10.1017/asr.2021.127 
puissante de relativiser et de décentrer l'institution est de documenter et de mettre en valeur les histoires et les récits de marginalisation, d'échec et de déconnexion des Noirs.

Resumo: O mito de Oxford, que ecoa e reproduz a ideologia de um imutável mundo de jovens brancos, é um tropo comum em muitos filmes e obras literárias. A esta visão, porém, sobrepõem-se e subjazem contratradições que descentram Oxford e, em vez disso, inserem Oxford de pernas para o ar noutras epistemologias, geografias e redes. Algumas tentativas de transformação de instituições elitistas como Oxford contribuem inadvertidamente para prolongar o centramento dessas mesmas instituições. Coetzee defende que, para relativizar e descentrar a instituição, em vez de nos focarmos em histórias sobre a crescente excelência e o crescente sucesso Negros/ negro na Universidade de Oxford, é mais eficaz documentar e destacar histórias e relatos sobre a marginalização, os fracassos e a segregação dos Negros.

Keywords: decentering; Black counter-narratives; Oxford University; Stuart Hall; \#RhodesMustFallOxford

(Received 23 July 2020 - Revised 24 October 2021 - Accepted 02 November 2021)

In Jean Allman's 2018 presidential address to the African Studies Association, "\#HerskovitsMustFall? A Meditation on Whiteness, African Studies, and the Unfinished Business of 1968," Allman called for self-reflection on the part of institutions and the association (2019). Her argument presented a synthesis of the many "attempts at constructing a counter-narrative of the ASA's origins and of the ruptures it has experienced, a counter-narrative aimed at coming to terms with the ASA's position in the racial landscape of knowledge production about Africa" (2019:8). In reflecting on the histories of the ASA, Allman argued, she wished to avoid a "comforting narrative of ascension (as opposed to declension), with its comfortable tropes of expansion, diversity, and inclusion" (2019:9) and instead to seek out the moments of failure, rupture, and marginalization in the history of the association.

In this article, I heed this call and focus on one particular institution, Oxford University, and the racialized narratives and counter-narratives through which it has been debated in the global imagination. I argue that, instead of focusing on histories of ascendant Black/black achievement at Oxford University, paying attention to histories of failure and disconnection offers a more powerful way to relativize and decenter the institution. ${ }^{1}$ The disciplinary vantage point for the article is twofold: I ask questions to do with time and historical change that have been formulated in African popular cultural studies, a field that pays persistent attention to social change (Barber 2018; Newell \& Okome 2014). I approach Oxford University comparatively, via the socially engaged scholarship from Nigeria which analyzes campus experiences, and which is mostly produced by early career scholars. Oxford University is thus inserted into a set of questions and timeframes that 
marginalize and decenter it from a centering to which the \#RhodesMustFallOxford movement has inadvertently contributed, as I argue below.

I make my decentering method concrete by approaching Oxford via Lagos, and by commenting on the socially engaged scholarly traditions that characterize the Lagos Studies Association's annual conferences. The questions asked here about the role of a university, and the function of higher education, provide a useful lens through which to understand the longer histories of \#RhodesMustFallOxford and the counter-narratives about Black experiences of marginalization and despair at Oxford University. Approaching Oxford through the socially engaged agendas of early career scholars in Nigeria relativizes Oxford's sense of itself as a (or even as the) center. In the section following this comparative argument, I contextualize \#RhodesMustFallOxford within an ongoing tradition of ethnographies and accounts of Black lives at higher institutions of learning, and in particular at Oxford. I discuss the dominant representation of Oxford University in popular culture, namely that of a space of gilded white youth whose concerns and politics are closely aligned with the ruling classes. In tension with this version of Oxford, there exists a proliferation of intersectional counter-narratives which crisscross the official, dominant, and most visible mapping of the city and the university.

In attempting to tease out some of the tropes in the Oxford countertraditions, I am inspired by the reading strategies of Christina Sharpe in In the Wake (2016), in which she analyzes the "orthography of the wake," imaginatively tracing the routes and mechanisms of what she calls "wake work." Another inspiration is the work of Stefano Harney and Fred Moten, who describe the activist focus of their attention in The Undercommons: Fugitive Planning $\mathcal{E}^{2}$ Black Study as the "refugee colony, [the] gypsy encampment, to be in but not of" the university. They write of the urgency not of absorption into existing university structures, but instead of disappearing into "the underground, the downlow lowdown maroon community of the university, into the undercommons of enlightenment" (2013:26). Their argument makes use of images of burrowing and borrowing and insists on the same overlapping timelines and epistemologies on which my own argument relies.

In writings that utilize the symbolic significance of Oxford University's underground spaces, Stuart Hall and Simon Gikandi, whose writings on Oxford I discuss in some detail, map Oxford as viewed from elsewhere, from somewhere with social justice agendas that do not center Oxford. The spatial organization of Oxford University, with its crypts and underground tunnels that create an alternative map underground, richly evokes the parallel and invisible spaces where Black scholars are often experientially located. These vaults and tunnels underneath the cloisters and courtyards have provided a memorable set of images for counter-traditions, and for what lies buried in the crypt.

Before we enter through the ancient doorway that leads into the green and secluded fellows' garden, I wish to locate the reader in a very different intellectual and social space. Over the past years, I have been involved in an ongoing collaborative project associated with the Lagos Studies Association conference series. ${ }^{2}$ Called "Campus Forms," this project has brought 
together scholars from a range of disciplines to discuss and to analyze university and campus life as a particular scene of experience, and to develop arguments about the ways in which Nigerian university campuses have shaped the cultural and expressive lives of students as well as of their lecturers. The Lagos Studies Association has invested time and resources in a younger generation of Nigeria-based and diasporic scholars, in collaboration with the strong existing networks of mentoring and intellectual development already practiced at Nigerian universities. In 2019, the Association launched an ambitious program called the "LSA Women's Mentoring Network," in recognition of the need to pay particular attention to the development of women scholars. The annual conference explicitly aims to address the gender imbalances in the global academy, and the Association has become known for working actively toward gender equity. The intergenerational conversations of the Association take place each year during the conference sessions and alongside the extensive mentoring program, and they are carried on over convivial meals overlooking the Lagos lagoon; the sociality and community spirit of the conference are its distinctive features.

Recurring themes in the Nigerian Campus Forms discussions have included sanitation and living conditions on campus (Omotayo 2019); sexual conduct and misconduct such as the events related to \#SexforGrades (Akande 2017; Ugah 2021); and literary representations of campus life (Kofoworola 2020); alongside analyses of films and television shows set on campuses, such as the film Citation and Funke Akindele's ongoing serial Jenifa (Ogunoye 2019; Okunlola 2020); and discussions about the alternative forms of self-making available to young people (Olofinlua 2020; Ugah 2019) for whom higher education all too often is simply another form of what Alcinda Honwana has memorably termed "waithood" (2019). Nigerian campus forms, this ongoing project has made evident, are characterized by genres of complaint and dissent, and are informed by questions about the value of university experience and the cost (financial and otherwise) of higher education. The socially engaged research conducted by this network of scholars is notable for the strong social justice agendas, a feature also of many of the campus novels and films and campus ethnographies discussed in the sessions at the annual conference. ${ }^{3}$

During the Covid-19 pandemic of 2020, The Lagos Studies Conference did not take place, and I found myself spending June not in Lagos at the conference overlooking the University of Lagos gardens and the lagoon, but instead in Oxford, the city where I have lived for more than twenty years. The bucolic spaces of Oxford University present a sharp contrast to the socially engaged campus forms of the Lagos-based research network, and never more so than during the isolating months of the pandemic. Walking through the Oxford University Parks during the daily exercise allowed under pandemic restrictions, I would come across some of the few students remaining in campus accommodation, mostly African students who had been unable to travel home. A number of these young people had been active members of the student organizations whose activities enable and document the 
ambivalent experiences of Black and African students at Oxford. During the pandemic, an upside-down world meant the university spaces briefly seemed to belong to them.

In the edited volume Rhodes Must Fall: The Struggle to Decolonise the Racist Heart of Empire, the editors (Roseanne Chantiluke, Brian Kwoba, Oluwafemi Nylander, and Athi Nangamso Nkopo) make reference to ethnographies of Black academics' experiences at Oxford: "As race-conscious Black students, we variously sought out spaces to engage in politically progressive and Blackpositive spaces in the years immediately preceding the Rhodes Must Fall in Oxford (RMFO) movement" (2018:14). The account in this book documents what they found upon arrival at Oxford. Other existing ethnographic projects documenting (and shaping) Black-centered academic life at Oxford include the Oxford University Student Union's Campaign for Racial Awareness and Equality (CRAE), which collects data on the social and academic experiences of Black and Minority Ethnic (BME) students. They refer to data drawn from these studies (2018:17), mapping an oppressive racial atmosphere. Yet there are also the organizations and associations that enable Black-centered space-making (like the convivial groups I met in the parks). These include the Oxford Africa Society which (before Covid restrictions) organized Afrobeat parties and other social and cultural events for graduate students, and the African Caribbean Society which did the same for undergraduates. As many Black academics for generations have done upon their arrival in Oxford, one cohort founded an organization that served the purposes of their own here and now: the Oxford Pan-Afrikan Forum (OXPAF), which "began as an effort to explore what it means to be Black and/or African at Oxford, the political and historical context and significance of these identities, and how people of African descent from the continent and the diaspora can build unity and solidarity" (2018:17). These organizations and the documents they have produced serve a double purpose, to document and to testify, but they function also as an enabling guide to those who come after them.

This informal curriculum, made up of accounts of experiences, is part of a well-established tradition of writing, across many genres. In the commentaries on campus or university novels (that is, novels set at universities and based around the lives of students or faculty), scholars often remark on how readers use the novels as guidebooks, learning about places they dream to occupy or are about to enter. Just like travel guidebooks do, these novels create and replicate tropes and reinforce existing images and assumptions. Campus or university novels, as well as non-fictional accounts of time at university, (in this case the University of Oxford) have long functioned as such guidebooks. Many readers, including Black academics and students, comment on the books they had read before their arrival, and how this shaped their insertion into Oxford. In feminist literary critic Elaine Showalter's study of the academic (or campus) novel, Faculty Towers: The Academic Novel and its Discontents (which is about the U.S. academy, not about Oxford), she writes of how she took "an immigrant's passionate ethnographic interest 
in the details of academic manners" in academic novels, reading them as a form of self-help (2005:xx). Showalter was what she calls a "faculty wife," and through this marginal position took an interest in narratives of campus life. Her reading of academic novels was an activity that she used to learn about the world into which she was inserted upside-down and at odds. She read these novels "for lessons" (2005:52), arguing that women readers such as herself could learn about the academic rules and the hidden curriculum from novels (2005:70). Campus novels and ethnographies written from the margins, such as those written by Black academics, can similarly be read as activist self-help and survival manuals, self-conscious reports not from the center.

As forms of radical self-help, there are many projects by Black academics that compile such auto-ethnographies, from a range of locations and epistemic traditions. Recent examples include the edited collection Surviving Sexism in Academia (Cole \& Hassel 2017) and the ongoing publications and activist work of scholars such as Sara Ahmed on complaint and diversity within institutions (2012, 2021). The Campus Forms network of Nigeriabased scholars documents the experiences of their peers as university students, as a record and an accusation against those who abuse power. Tell! Publications has published the MONUS Anthologies - a collection of "true life stories of Nigerian university students" documenting a range of experiences and dedicated to "all University Students in Nigeria... [w] understand that the hustle is real and we pray that God grants all our efforts with success..... eventuarry [sic]" (Soyombo 2019). Temitayo Olofinlua, a scholar based at the Institute of African Studies at the University of Ibadan, has written about this activist project's use of fugitive documents: "In a world where censorship is rife, MONUS leverages the internet to collect, curate and disseminate stories that speak truth to power-campus authorities and the larger world. Finally, the article highlights the different ways these stories centralise the complicated, even flawed, relationship between the town and the gown" (2020). Another example is the recent edited volume from South Africa, Black Academic Voices: The South African Experience, which includes contributions from a group of Black scholars (mostly but not all women) who have written down firsthand experiences of being Black academics in a collective project of "history-making" (2019:2), inserting their autobiographical accounts into existing narratives of what a university is and can be. Many of these texts are future-oriented, and they combine what Sara Ahmed calls complaint discourses with transformative agendas (2021).

There are long and well-established counter-traditions of and from Oxford which link up with these discourses from elsewhere. These socially engaged and resistant responses to Oxford are generated from a range of intersectional positions, and a history of these existing and generatively evolving counter-traditions would be a valuable project (see, for example, Posh, the play by Laura Wade that centers on gender and the class divide [2010]). The counter-narratives that are the focus of the current article are provided by some of the Black scholars, real and fictional, who have written 
accounts of their time at Oxford. Constructing such counter-narratives of life at Oxford University poses a challenge to ambiguously reparative celebrations of Black excellence, which risk upholding Oxford as center.

In his The Blackademic Life: Academic Fiction, Higher Education, and the Black Intellectual, Lavelle Porter writes that the Black academic is a lightning rod in contemporary politics. His argument is that "blackademics" (in the U.S., which is his focus) have needed to craft counternarratives in defiance of white supremacy. In his view, academic novels articulate Black intellectuals' skepticism about academic institutionality and the possibility of their inclusion in it. What does it mean, he asks, to be included in institutions that were founded on Black subjugation (2019:22)? Porter writes usefully about the "temporal turn" in Black studies in recent years, and about the concept of temporality as a physical phenomenon and a way of conceptualizing Black subjectivity (2019:115). Black studies, he concludes, is a project that intends to theorize and to understand where and when, rather than what and whom. In other words, it is not enough to point out (and to celebrate) the mere presence of individual Black students and staff members. Any effort to write histories of, and to reflect on, the university must have the experience of Black students, faculty, and administrators as a central component (2019:164) — and in particular, as I argue here, if these are histories of failure, marginalization, and despair. In recent years, the name of Oxford University has become associated not only with the manicured courtyard lawns and dreaming spires of popular imagination; increasingly the University has been mentioned in relation to the \#RhodesMustFall movement, the vexed and divisive legacies of the Rhodes Scholarship, and the links between the institution's wealth and histories of enslavement and profiteering. A significant example of Oxford counter-traditions would be that of the Oxford branch of \#RhodesMustFall. Yet the media attention to and prominence of \#RhodesMustFallOxford risks centering Oxford once again, and obscuring that the Oxford movement was subsidiary to the events that originated in South Africa. Even in this narrative, there is a centering of elite institutions, as the attention to the historically white University of Cape Town and its Rhodes statue has overwritten the leading role played by less visible and less elite institutions such as the historically Black universities where alternative chronologies locate the origins of the various South African student movements of 2015 (Ndlovu-Gatsheni 2018; Nyamnjoh 2016).

A historically and symbolically significant attempt at complicating Oxford University's histories, also associated with \#RhodesMustFallOxford, is the call for greater representation of Black professors and students. In order to address the historical absence and exclusions of Black scholars from Oxford, many have argued for increased representation and for greater recognition of Black excellence. In this narrative, Black (and in particular Black African) scholars assert ownership of Oxford and of its legacies of "excellence"; but here, too, the narrative works to delete that which it intends to promote. The institution gains by using this "global excellence" narrative to enhance its own image, selfexculpatingly sanitizing its past. Recently, Pamela Roberts has written an 
important history called Black Oxford: The Untold Stories of Oxford University's Black Scholars (2013), which celebrates Black achievement at Oxford University. Roberts embarked on her project to prove and to document that Black scholars have been studying at Oxford for more than a century, and the research she did for this book has laid the foundations for many projects to come. Alongside narratives of excellence and achievement, her book also includes references to the careers cut short by racism, the lack of institutional support, and experiences of cultural alienation, thus supplementing and relativizing the narrative of exceptional Black achievement.

The reasons for wishing to celebrate Black excellence are clear and urgent. At Cambridge University in the UK, for example, a group of graduate students led by Dr Njoki Wamai (a Kenyan scholar now based at United States International University-Africa in Nairobi, Kenya) founded a society called The Black Cantabs, "a counter-history project" with the historical and political aim "to uncover and preserve the legacies of Black alumni," "to critically intervene in the constructed narrative of Cambridge, and to place Black students in the institution's past, present, and future." 4 While the Black Cantabs project celebrates pioneers and trailblazers, the political project is not simply to insert Black excellence into the pre-existing narrative of Cambridge University. Instead, what the Black Cantabs project does is to insist on the importance of creating and strengthening the links within the blackademic tradition at Cambridge. Such a timeline for Oxford University would be able to account for success but also to acknowledge the blockages, interruptions, and even failures that make up the history of the institution's Black presence through time.

In the remainder of this article, I go in search of abandoned and failed doctoral dissertations, forgotten and unopened trunks, and memoirs of despair and anger, to plot the tropes of a counter-history of Black academics' experiences of and at Oxford. ${ }^{5}$ Characteristic of this counter-tradition is the foregrounding of connections to the times and spaces of elsewhere and the creation of forms of sociality that exceed the exclusive spaces of the formal high table dinners and the fellows' common rooms. Instead of centering Oxford, these counter-narratives place Oxford within a global network of different and relativizing temporalities, and as one among many institutions of knowledge production, provincializing Oxford. Alongside the autobiographical accounts and documents of complaint, the archive of identity papers, visa applications and other travel documents, applications for funding, and representations to admissions and promotion committees form an underground archive, mapping the routes into, as well as the exclusions from, the spaces of Oxford. These travel papers thus map another way of connecting Oxford up to other locations, and of relativizing its imagined geographical centrality.

My argument proceeds by drawing on a series of texts by and about Black academics at Oxford, constructing such alternative maps of space and time. I begin by analyzing what is distinctive about representations of Oxford time, and move on to document the counter-narratives of Oxford from the point of 
view of Black academics and scholars, showing that these works contribute to a decentering of Oxford. I provide an overview of some accounts of Black lives at Oxford University, contrasting these with the sometimes self-forgiving and triumphalist narratives of increasing "diversity" and reparation. I draw out some of the recurring tropes from literary and autobiographical texts by and about Black scholars, showing the ways in which what can be called the myth of Oxford is reinterpreted, relativized, and resisted in their texts.

Oxford, as setting and as idea, has played a unique and disproportionately large role in shaping global versions of campus forms, in particular in sartorial self-styling, and through the genre of the campus or university novel, a disproportionate number of which use Oxford as their setting (Carter 1990:4). What characterizes this set of representations-what has often been called the "myth of Oxford"-is the persistence of images of affluent white youthfulness and of enclosed and walled green spaces, unchanged and unchanging through generations. ${ }^{6}$ The tropes that recur in representations of Oxford University create a particular experience of space and time, what I term here "uchronic": a time and space disconnected from the demands of history, and where the enclosed nature of the walled garden is naturalized and mobilized to defend against demands for social and political change. A theme common to many of the popular representations of Oxford University, in literature and on film, is precisely of the university and the city existing outside of chronological time, instead remaining as a dream-like island locked in its own mythical time: Oxford time. The argument used most frequently for the retention of imperial symbols, such as the statue of Cecil John Rhodes, is to call "for a recognition that views from the past need to be judged in their historical context." "Such dehistoricizing demands that we recognize the "historical context" of symbols and statues require of us to remove ourselves from our own context and our own time, and to enter the timeless time of Oxford.

Let us now explore and enter in our imaginations that mythical space of the locked garden. The trope that recurs in uchronic accounts of Oxford is the secluded and walled garden, which is entered through a door unlocked for your benefit, on an afternoon in late spring or early summer. To those who live in this city without a University of Oxford staff or student card (as I have done for twenty years), this means that much of the central city remains inaccessible. The heart of Oxford City is the cobbled square surrounding the dome-roofed Radcliffe Camera, the square from which the many other colleges radiate out, each with its own walled gardens and locked doors. Walking through the center of the city, one might see a sprig of blossom overhanging a wall, or glimpse a courtyard through an open doorway-but this is a space that one may never enter. Alternative maps of Oxford exist, shaped by whether one is either locked in, or out, of the University spaces. In books written for children, the two characters most closely associated with Oxford are Alice (from the pair of fanciful novels by Charles Lutwidge Dodgson who published under the pen name Lewis Carroll), and Lyra from Philip Pullman's His Dark Materials novel cycle. Both Alice and Lyra find doorways that give them entry to another world, and both can bend time, yet 
remain in the present moment. Alice famously falls into a rabbit-hole, emerging after pages of adventures, to find that not a moment has passed. Lyra is able to travel between alternate and overlapping worlds that do not share the same timeframe and, at the end of The Amber Spyglass, she and a boy named Will who inhabits a different time (resembling our own) resolve to meet (virtually) on a certain bench in the University's Botanical Gardens every midsummer day. The walled space of the Botanical Gardens, where an actual bench now stands, is a pilgrimage site, not only on midsummer day each year, for visitors to the gardens who wish to share the imagined space, inserting their own time into the repetitive and cyclical uchronic time of Lyra and Will. If you have an Oxford University staff or student card, you may naturally enter for free. During the Covid-19 lockdown of 2020, I walked around the center of Oxford to experience the city's depopulated timelessness, and Oxford University never seemed more like itself than it did during these eerie summer days. It appeared as a stage set, dressed up as its own timeless fake self; and of course, all the doors were locked.

No doubt the most formative set of images to have shaped the way Oxford has come to be held in (false) memory is the 1980s Granada Television series adaptation of Evelyn Waugh's novel Brideshead Revisited. What many remember as lasting for hours (or pages in the case of the novel) is a small fragment onlyand this is how Oxford time works, extending itself outside and beyond the possible. The voice of Jeremy Irons, who plays Charles Ryder in the television series, reads these words, which loop out like a soundtrack across the city:

That luncheon party—for party it proved to be-was the beginning of a new epoch in my life.

I went there uncertainly, for it was foreign ground and there was a tiny, priggish voice in my ear which in the tones of Collins told me it was seemly to hold back. But I was in search of love in those days, and I went full of curiosity and the faint, unrecognized apprehension that here, at last, I should find that low door in the wall, which others, I knew, had found before me, which opened on an enclosed and enchanted garden, which was somewhere, not overlooked by any window, in the heart of that grey city. (1945:32)

The novel (and the television adaptation, which follows its form closely) opens with the protagonist, Charles Ryder, now a thirty-nine-year-old captain in the British army during World War II, reminiscing about the Arcadia he had lost, twenty years ago. In those days, he recalls, Oxford "was still a city of aquatint" (1945:23) and in "her spacious and quiet streets men walked and spoke as they had done in Newman's day; her autumnal mists, her grey springtime, and the rare glory of her summer days-such as that day-when the chestnut was in flower and the bells rang out high and clever over her gables and cupolas, exhaled the soft airs of centuries of youth" (1945:23). Here are the essential elements of uchronic Oxford: the quietness of the streets, the soft seasons, the walled gardens in bloom and-most important of 
all-nostalgia for (white male) youth that lasts for ahistorical centuries, unchanged and unaffected by a wider world. The loss of this world happens long before the end of Book 1 (out of 3), but most readers forget the rest of the novel and of the television adaptation, remembering only the eternal summer's day when the "gillyflowers bloomed... and the chestnuts lit the streets and the warm stones strewed their flakes upon the cobble" (1945:135). The television series, also named Brideshead Revisited, had a surprisingly significant impact on a certain brand of what in the U.S. might be called "preppy" fashion, and has contributed hugely to the fabrication of the myth of unchanging Oxford. The whiteness of the film's aesthetic is striking-the men's suits are pale, Ryder's beloved Sebastian is blond (which he is not in the novel), and even the famous teddy bear Sebastian clutches (without any explanation ever provided for this babyish behavior) is blond.

In writings on Oxford, the tropes from Brideshead Revisited are themselves endlessly revisited and recycled. In South African born writer Justin Cartwright's small book This Secret Garden: Oxford Revisited, he writes: "Oxford is many things. But it has a symbolic meaning well beyond its buildings, gardens, rituals and teaching. It stands for something deep in the Anglo-Saxon mindexcellence, a kind of privilege, a charmed life, deep-veined liberalism, a respect for tradition" (2008:vii). In case it is not clear how enthralled he was, and remains, he continues:

From the moment I arrived at Trinity College in the mid-sixties, I was in love with Oxford. It plumped up my dry colonial heart; I loved the first autumn term, the darkness, the gowned figures on bicycles, crumpets after rugby, the pale-though not very numerous-girls, the extraordinary buildings and the water running through and around the town. I felt as if I had always known the place, or some simulacrum of it, in another or parallel life (2008:viii).

When he returns to Oxford after many years, to do the research for his book, he finds himself repeatedly on the brink of "self-regarding tears" (2008:10), photographing everything in this freakishly photogenic city, because he finds it "difficult to distinguish between [his] memories of Oxford" and the city in front of his eyes. These sentimental re-encounters seem to confirm that he is becoming one again with his youthful self, growing ever younger as he records the city. As he eats a club sandwich, late one night, he has a "mystic revelation": "There I am in the mirror, disappearing in an arc of sadly distorted images, when it comes to me: it's no great insight but I see that Oxford, for all its ancient and fraying stone, for all its processions of greyhaired men and women, for all its millions of books, is in essence a city of youth: the books, the dons, the buildings are sets and props against which youth parades itself. For three or four years the young pass through Oxford, a changing cast, but unchanging in their youth." (2008:14). But as he admits, even his very personal mystical revelation is itself a recycled one.

As an imposter version of his younger self, Cartwright asked an acquaintance to take him for an undergraduate tutorial (2008:58). When he turned 
up for the tutorial, his pretend don "was waiting in his new study, looking out over a small garden towards Front Quad, a perfectly framed view, a distillation of Oxford" (2008:61). The Oxford tutorial, famous for the intimacy and personal attention, miniaturizes the world, and Cartwright writes that it is "prized more as cultural capital, part and parcel of the whole Oxford experience, than for its own sake" (2008:75). Developing this theme of becoming again an undergraduate, he applies for a reader's card to the University library, the "Bodleian," and is "immoderately moved" (2008:90) to find his name is still on their system and he is "invited to inhabit this astonishing place, as if, somehow, [he] was a part of it, as if [he] had never left the happy band" (2008:90). The desire for youth reaches a peak when he stumbles across an exhibition of memorabilia of John Betjeman (himself the author of a worshipful book called An Oxford University Chest), including objects such as Betjeman's teddy bear and toy elephant, "both extraordinarily worn from fervent affection" (2008:167). This bear, he claims, inspired the bear that Sebastian Flyte clutches in Brideshead Revisited. Such is Oxford time; it transports the alumnus back to a communally shared and unchanging moment of youth, back to his imagined intellectual babyhood.

Another memorable account of life at Oxford that dwells on some of these same tropes comes from the autobiography of African literature scholar Eldred Durosimi Jones, who spent time at Oxford University in the 1950s. He was the author of The Physical Representation of African Characters on the English Stage during the 16th $\mathcal{E}^{2}$ 17th Centuries (1962) and of Othello's Countrymen: The African in English Renaissance Drama (1965) (which won the criticism prize in the first World Festival of Black Arts held in Dakar in 1966), and the editor of many literary journals. His scholarship hinged on two themes: Black characters and figures during the English Renaissance and on the English stage, and the sense of the crucial importance of Africa-centered scholarship. His autobiography, The Freetown Bond: A Life Under Two Flags, is in some ways a reckoning with the ambiguous role Oxford University played in his life. He revisits some unhappy incidents related to his application process and the patronizing and racist responses he received, recalling the intrusive questions about his financial as well as his academic "worth" (2012:46-47), rehearsing old grudges and replaying these scenes with some bitterness.

Yet in other sections of the autobiography, he recounts the pleasure he took in the rituals of his life as a member of the university. Jones is at pains to sketch a view of his time at Oxford, where he was a student at Corpus Christi College, as a time during which he and his peers built global connections, yet the description borrows self-consciously from the Brideshead iconography: "Bowls in the Fellows' garden on summer evenings, play readings and dramatic performances, sing-song sessions in rooms, coffee evenings with the chaplain, choir practices, music ensembles in addition to the usual college sports, brought this small community into constant contact with each other... We cycled on summer afternoons to Blenheim, took tea in Burford, Banbury and villages in the Cotswolds and spent others floating on the river. The staples of undergraduate social life were the afternoon teas-integral to 
which were toasted crumpets (among one's earliest purchases was the sixpenny toasting-fork from Woolworths) - and the after-dinner coffee before the late evening study-session began" (2012:51). A serious scholar, not wishing to be misunderstood, he also insists that his time was mostly spent reading and studying.

The spaces of leisure and sociality that map the Oxford of Brideshead Revisited (a novel in which hardly anyone ever opens a book or enters a library) are overlaid in Jones' memory with another, interior, map: "As one browsed freely in Blackwell's, Oxford's leading bookshop, a book might lead down an alleyway into a new interest" (2012:54). As Jones' mind and knowledge expanded, a new map of the city and the world unfurled within him. He writes:

My first visit to this library gave me a rude introduction to the English climate. Two hours of reading in artificial light in the comfort of the Camera had turned the afternoon into night and I emerged into a totally different landscape. Where had the afternoon gone to leave me without a compass in this academic wilderness? In the carrels of my own college library, I spent many happy hours with the volumes of the Oxford English Dictionary, following the journeys of individual words down the meanderings of English history. It was this freedom (and still is, I hope) that helped me to make an Oxford education such a liberating experience. (2012:54)

In his autobiography as well as in his scholarship, Jones was intent on placing Africans and African literature centrally within a global network of knowledge. The interior map that places Oxford within a wider network of relations and forms of knowledge is described using language of intimacy and warmth, contrasted with the grey season of "this academic wilderness."

Sarah Ladipo Manyika's novel In Dependence (2019, originally published in 2008) opens a decade after Jones spent his time in the wilderness of Oxford, and closes in 1994 with a scene that evokes Oxford University at its most ceremonial and most "traditional": an Encaenia ceremony in the Sheldonian Theatre, during which the Nigerian-born professor and protagonist Tayo Ajayi is awarded an honorary doctorate by his alma mater. Encaenia is the ceremony at which the University of Oxford awards honorary degrees to distinguished men (and more recently some women) and commemorates its benefactors. The ceremony is held annually on the Wednesday of the ninth week of what is called in the Oxford University calendar "Trinity Term" (in the springtime), and the closing pages of the novel contain a description of cows basking lazily in the late afternoon sun along the river, on a piece of land in the center of Oxford called Christ Church Meadow. The narrative arc which started in the 1960s brings Ajayi back to the city of dreaming spires and reunites him with the (white) British woman he might have married. As they walk through this landscape of a thousand tourist photographs, he exclaims: "Look at Christ Church, and all of this. If I close my eyes, it could still be 1964. The sounds are the same: the bells, the coaches 
shouting to their rowers in the distance. There is even the same smell of grass and river" (2019:278). The timeline of the novel includes Nigerian independence (October 1, 1960), but it is Oxford and Oxford time that stands at the center of the meanings of his life and of the novel. Embracing his sweetheart of thirty years ago, Professor Ajayi forgets about his wife who is waiting for him, along with the distinguished guests at the reception in his honor, and enters a time outside of time-Oxford time. Being reunited with the love of his undergraduate years, seated here watching the uchronic cows, Ajayi forgets the demands and political and ethical obligations of his life beyond Oxford. In 1994, the novel seems to suggest, many of the prejudices he experienced at Oxford in the 1960s have been transcended, and there are now, in this "new" time, opportunities to honor Oxford's blackademic alumni.

Yet there is another plotline, interrupted and aborted, running through the novel, of a talented Nigerian woman also studying at Oxford. Her name is Christine Arinze, and she commits suicide, so the novel reveals, because of her fear of failing and the pressures of racism. This is an all-too-common narrative within the Oxford blackademic tradition, and the underground discourses about the despair experienced by talented Africans studying at Oxford is a vast and paralyzing archive. In literary circles, the most famous Black Oxonian is undoubtedly the Zimbabwean Dambudzo Marechera, whose spectacular self-destructiveness has become incorporated into Oxford lore. The anecdotes about Marechera often dwell on sensational details (and Tinashe Mushakavanhu's work comments on this spectacularizing impulse in the scholarship); but there are quieter archives of despair and marginalization that deserve attention and that have shaped intellectual schools and traditions.

One such an archive is that created by Stuart Hall, whose name is not often mentioned as part of the histories of Oxford University (although some such as Robbie Shilliam place him centrally). ${ }^{8}$ Yet his time at Oxford University is described in his autobiography Familiar Stranger: A Life Between Two Islands as "the central contradiction of [his] life" (2018:12), and he writes that his time at Oxford University "changed [him] irrevocably, almost none of it in ways [he] had anticipated" (2018:149). Hall locates the birth of cultural studies in Rhodes House Library (2018:248), the library that used to house the University's African Studies collection in the building named after Cecil John Rhodes. This memorable scene, of Stuart Hall sitting in Rhodes House Library, becoming the radical intellectual and one of the founders of the socially engaged scholarly field of cultural studies, is one of the crucial references for Black academics at Oxford. Hall writes that the spectacle of Oxford that pretends to be unchanged "unfolded in front of [him] like a movie, knowing all the time it was a facsimile caricature of itself" (2018:157).

Stuart Hall's Rhodes Scholarship to study at Oxford University represented for his parents the fulfilment of a dream, and Hall's arrival in Oxford is one of the stories of Black excellence and Black attainment that are comfortable to remember, and that are used to build the narrative of Oxford 
University as the global university welcoming of all who are "excellent." Arriving in Oxford, Hall had a large trunk which his mother had packed in anticipation of his life at Oxford. This trunk, so heavy it seemed like "a drowned body that had floated to the surface" was, to the young Oxford student, a piece of "baggage from the past" (2018:155). It was carried into the basement of Merton College where it was left unopened and, writes Hall, "consigned ... back to the past."

\begin{abstract}
I sometimes wonder what became of it. With its rounded top and steel hoops, it was a relic of all I was leaving behind. It belonged with the imported things my mother always insisted on using as a token of our abiding loyalty to the colonial version of modernity and sophistication.... As was fitting for an object loaded with ambiguous significance, weighted down with pretentiousness and aspiring to what it could never be, it was for me already an anachronism, out of time and out of place. I abandoned it with relief. For all I know it's still there. (2018:155)
\end{abstract}

The trunk's contents were intended to inaugurate a life at Oxford University and to enter the "modern" time of the university seamlessly and successfully. For Hall, however, the trunk and its contents instead represented the ways in which his arrival at Oxford University was a continuation of "a long-running story that had begun centuries earlier" (2018:154). His phrasing draws attention to the uneven temporalities that disenchant the myth of timeless Oxford. While for his parents his arrival at Oxford was a moment of triumph and the fulfilment of long-held dreams, for the young Hall this meant something different, and the meaning of this juncture in his life was instead "a journey to the shattering of illusions and an inauguration of a protracted and growing sense of productive disillusionment" (2018:149). In the eyes of his mother in particular, Hall's arrival at Merton College was evidence of his insertion into Oxford time (the time of success and achievement), while for Hall himself, his arrival was marked by being "inserted into history by negation, backwards, upside down, dispossessed... out of place or displaced, transported" (2018:61). It is possible the trunk remains in the cavities under the college to this day.

In his writings about Oxford and its effect on him, Hall reports that his initial response was to sink into silence, evasion, and disavowal (2018:61), living in the small spaces in which many Black academics experience their institutional lives, tolerated for the duration of their degrees (and visas) until it is time for them to go "home" (2018:158). ${ }^{9}$ And it is out of this silence and evasion, he writes, that his life project came to be born: "out of such failures are critics and theorists made" (2018:132). One needs to bend the word "failure" to make it fit Stuart Hall, whose enabling life and visionary scholarship has influenced so many. The word failure here comes to describe a particular project, a project of radical disengagement. In terms of my argument about time, the "failure" is a commitment to disenchanting the uchronic myth of Oxford and showing it up as a facsimile or fake version of itself. 
Hall refers to Oxford as a "distillation" of English class hierarchies (2018:157), and as central to "the English sense of always being in place" (2018:157). Instead, the radical disengagement Hall cultivated in himself sought to make meaning through disjuncture, by paying attention to filaments that are broken, mediated, subterranean, unconscious (2018:71), what he calls "the dislocated presence of [a] history that militates against our understanding of our own historical locations" (2018:71). In this way, then, Oxford University provided Stuart Hall with the material he needed to develop his critical consciousness. His intellectual turning point occurred when he realized this: the more disengaged he became from the ethos and atmosphere of Oxford University, the more he came to develop the radical outsidership that remained his signature. This marked the beginning of a lifelong intellectual disengagement from Oxford and all it stood for (2018:223), and in its place a growing political involvement with the "rebel enclaves" of Oxford city (2018:227), far beyond the walled gardens. This memorable set of images shapes the metaphors through which his autobiography is structured: a life between two islands, living on the hinge between the colonial and postcolonial worlds without entirely belonging to either, but fully aware of the interdependence of both worlds (2018:11). His time at Oxford was crucial for developing the methodologies for which Hall was to become famous, and to his academic work which showed how ideology invades language and shapes perception. He regarded language as always operating within a framework of power and ideology. His attention to unruly audience responses meant that he saw us as producers and consumers of culture at the same time, resisting coercion and fabricating dissent rather than manufacturing consent. The dense semiotic and ideological structures shaping perceptions of Oxford University lend themselves ideally to his method.

Hall's autobiography can be read as an ethnographic study of Oxford University as experienced by someone who did not inhabit the symbolic space of the university but instead found and excavated tunnels underneath it, thus experiencing a version of Oxford while being haunted by the racialized and slave pasts still inhabiting the historical present (2018:71), and watching the colonial world continue to unfold within the post-colonial world, in the wake of the aftermath (2018:22). Strikingly similar for its use of tropes of burial is Simon Gikandi's chapter on Oxford in his book Slavery and the Culture of Taste. Gikandi is interested in particular in All Souls College and the Codrington Library, with its many connections to Hall's West Indian birthplace. ${ }^{10}$ What are we to make, Gikandi asks, of those experiences and losses that cannot be acknowledged because they are at odds with the narrative of modern identity (2011:ix)? To name these events, he argues, would be to contaminate the modes of our self-understanding. Gikandi describes his project as one in search of a language for what lies buried in the crypt (2011:x), buried under the beauty of the university-alongside Stuart Hall's trunk. Gikandi's project does not aim to place the disavowed and marginalized figure of the slave or the Black person in a recovered central position. This would risk reinforcing 
the ahistorical mythical sense of what it means to be in and of Oxford, seemingly offering repair but in fact simply burying discord. Instead, what Gikandi wishes to do is to develop a model for understanding history that can pay attention to two (or multiple) traditions at the same time. Through this approach, Oxford is understood always from elsewhere, inserted upsidedown into other epistemologies and time frames.

My own and related argument is that this insistence on multiple epistemic traditions and multiple locations, with Oxford inserted upside-down into other timelines and networks, is the crucial project of decentering its elite spaces. Using the insights of African popular cultural studies, with its focus on understanding historical change, we can disenchant and debate the racialized images through which Oxford has been constructed. Recurring tropes in this decentered version of Oxford privilege neither the garden nor the meadow, but instead the crypt, the tunnel, and the locked door. The tradition of Black academics' presence at Oxford University can thus be understood through the scattered archive of accounts of life at Oxford, an archive that draws attention to the breaks and discontinuities between Oxford time and the time(s) of Black academics at Oxford. The Black academic tradition at Oxford University is a project of denaturalizing and demystifying the uchronic time of the university. It does so not simply through a tradition of exuberant and reparative excellence, or by insisting on Black excellence. This archive of Black experiences at Oxford is more often than not shot through with despair, and it circulates informally as a submerged but coherent counter-narrative, tying together generations of blackademics.

Instead of centering Oxford time, these counter-narratives place Oxford within a global network of different temporalities and institutions of knowledge production. What Lavelle Porter calls the "blackademic" project is one that resists and troubles demands to understand the past "on its own terms"; instead, it asks that the present be understood in terms of many differently located pasts and presents. Hence, we can and should resist the call to recognize and appreciate Oxford University's timeless and "quintessential Englishness." In June 2016, when Oxford student Oluwafemi Nylander appeared at the front door of All Souls College, with a chain around his neck and "All Slaves College" painted on his bared chest, his actions drew on the well-established tradition of re-enactment, which has the intention of emphasizing the lived experiences of the legacies of slavery and enslavement and the ways these have shaped the present of Oxford. ${ }^{11}$ This was not the repetition of ritualized celebration so characteristic of the Oxford University calendar and constitutive of the myth of unchanging "tradition," but instead one that marked rupture. ${ }^{12}$ By enacting an enslaved person, Nylander was performing the entanglements between the past and the present, insisting that history is not only relevant but urgent. The radical project of blackademic Oxford is to break the spell, to disenchant the myth of timelessness and to insert the upside-down histories of resistance and non-compliance into the story of Oxford. While the fabrication and maintenance of uchronic time (as an alternative, fictional time characterized by 
the absence of change) is a central and dominant trope in literary and filmic representations of Oxford University, significant and urgent counternarrative traditions challenge this fiction of mythical time (as unchanging, "traditional," and outside history) and decenter Oxford and Oxford time. My focus in this article has been social change and how competing notions of temporality can be transformative, by privileging the blockages, interruptions, and even failures that make up the history of a particular institution's Black presence through time. To overlay this timeline onto the uchronic time of Oxford is an urgent and a radical endeavor, and one that brings the social justice agendas of scholars located elsewhere, such as in Nigeria, to the well-manicured spaces of Oxford.

\section{References}

Ahmed, Sara. 2012. On Being Included: Racism and Diversity in Institutional Life. Durham, North Carolina: Duke University Press.

- 2021. Complaint! Durham, North Carolina: Duke University Press.

Akande, Lola. 2017. What It Takes. Ibadan: Book Kraft.

Allen, Tim, ed. 2019. Okot p'Bitek, Frank Knowles Girling: Lawino's People—The Acholi of Uganda. Zürich: Lit Verlag.

Allman, Jean. 2019. "\#HerskovitsMustFall? A Meditation on Whiteness, African Studies, and the Unfinished Business of 1968." African Studies Review 62 (3): 6-39.

Barber, Karin. 2018. A History of African Popular Culture. Cambridge: Cambridge University Press.

Betjeman, John. 1979/1938. An Oxford University Chest. Oxford: Oxford University Press.

Black Cantabs Research Society. https://www.blackcantabs.org/.

Brideshead Revisited. 1981. Television Serial Produced for Granada Television, Directed by Charles Sturridge.

Carroll, Lewis (Charles Lutwidge Dodgson). 2013/1862. Alice's Adventures in Wonderland. Cambridge: Cambridge University Press.

Carter, Ian. 1990. Ancient Cultures of Conceit: British University Fiction in the Post-War Years. London: Routledge.

Cartwright, Justin. 2008. This Secret Garden: Oxford Revisited. London: Bloomsbury.

Chantiluke, Roseanne, Brian Kwoba, Oluwafemi Nylander, and Athi Nangamso Nkopo. 2018. Rhodes Must Fall Struggle To Decolonise The Racist Heart Of Empire, by The Rhodes Must Fall Movement, Oxford. London: ZED Books.

Coetzee, Carli. 2019. Written Under the Skin: Blood and Intergenerational Memory in South Africa. Woodbridge: James Currey/Boydell \& Brewer.

Cole, Kirsti, and Holly Hassel, eds. 2017. Surviving Sexism in Academia: Strategies for Feminist Leadership. Abingdon: Routledge.

Gikandi, Simon. 2011. Slavery and the Culture of Taste. Princeton: Princeton University Press.

Hall, Stuart. 2018. Familiar Stranger: A Life Between Two Islands. London: Penguin.

Harney, Stefano, and Fred Moten. 2013. The Undercommons: Fugitive Planning E Black Study. New York: Autonomedia. 
Honwana, Alcinda Manuel. 2019. "Youth Struggles: From the Arab Spring to Black

Lives Matter and Beyond." African Studies Review 62 (1): 8-21.

Johnson, Rachel. 1988. The Oxford Myth. London: Weidenfeld \& Nicholson.

Jones, Eldred Durosimi. 1962. The Physical Representation of African Characters on the English Stage during the 16th $\mathcal{E}$ 17th Centuries. London: Ifan Kyrle Fletcher

- 1965. Othello's Countrymen: The African in English Renaissance Drama. Oxford: Oxford University Press.

Jones, Eldred Durosimi, with Marjorie Jones. 2012. The Freetown Bond: A Life Under Two Flags. Woodbridge: James Currey.

Khunou, G., E.D. Phaswana, K. Khoza-Shangase, and H. Canham. 2019. Black Academic Voices: The South African Experience. Pretoria: HSRC Press.

Kofoworola, Kayode G. 2020. "Elitist and Popular Ideological Forms in Three Nigerian Campus Novels." Unpublished paper submitted to be delivered at the 2020 Lagos Studies Association Conference (cancelled).

Ladipo Manyika, Sarah. 2019/2008. In Dependence. Abuja: Cassava Republic Press.

Ndlovu-Gatsheni, Sabelo J. 2018. Epistemic Freedom in Africa: Deprovincialization and Decolonization. London: Routledge.

Newell, Stephanie, and Onookome Okome, eds. 2014 Popular Culture in Africa: The Episteme of the Everyday. London: Routledge.

Nyamnjoh, Francis. 2016. \#RhodesMustFall: Nibbling at Resilient Colonialism in South Africa. Bamenda: Langaa Research and Publishing Common Initiative Group.

Ogunoye, Oladimeji Raphael. 2019. "The Making of Campus Females: Towards the Poetics of Campus Female Characters in Nigerian Home Video Films." Unpublished paper delivered at the 2019 Lagos Studies Association Conference.

Okunlola, Omotola. 2020. "Nollywood, Campus Forms, and Postcolonial Pedagogy." Unpublished paper submitted to be delivered at the 2020 Lagos Studies Association Conference (cancelled).

Olofinlua, Temitayo. 2020. "Memoirs of Nigerian University Students (MONUS): Creating a Safe Space for Nigerian Campus Stories." Unpublished paper submitted to be delivered at the 2020 Lagos Studies Association Conference (cancelled).

Omotayo, Charles K. 2019. “'Shotputting' and Other Dirty Secrets: Students' Struggles Over Toilet Access in the Polytechnic of Ibadan, Nigeria.” Unpublished paper delivered at the 2019 Lagos Studies Association Conference.

Porter, Lavelle. 2019. The Blackademic Life: Academic Fiction, Higher Education and the Black Intellectual. Evanston, Illinois: Northwestern University Press.

Pullman, Philip. 2011. His Dark Materials Trilogy (including The Golden Compass, The Subtle Knife, and The Amber Spyglass). London: Scholastic.

Roberts, Pamela. 2013. Black Oxford: The Untold Stories of Oxford University's Black Scholars. Oxford: Signal Books.

Sharpe, Christina. 2016. In the Wake. Durham, North Carolina: Duke University Press.

— 2019. "Behind the Rhodes Statue: Black Competency and the Imperial Academy." History of the Human Sciences 32 (5): 3-27.

Showalter, Elaine. 2005. Faculty Towers: The Academic Novel and its Discontents. Oxford: Oxford University Press.

Soyombo, Fisayo. 2019. MONUS 2.0: Memoirs of Nigerian University Students. Nigeria: Tell! Publications.

Ugah, Helen. 2019. “'Whatever It Takes!' Financial Survival Strategies among Students of Obafemi Awolowo University Ile-Ife, Nigeria." Unpublished paper submitted to be delivered at the 2020 Lagos Studies Association Conference (cancelled). 
2021. "Reading Dina Ligaga's Women, Visibility and Morality in Kenyan Popular Media From Nigeria." Journal of African Cultural Studies. DOI 10.1080/13696815.2021.1917347.

Wade, Laura. 2010. Posh. London: Oberon Books.

Waugh, Evelyn. 2003/1945. Brideshead Revisited. London: Penguin.

\section{Notes}

1. I follow contemporary practices of writing Black with a capital, except where I use the term blackademic, which I quote from Lavelle Porter, who does not use a capital letter.

2. For more on this conference series and the programs of the Lagos Studies Association, please see https://lagosstudies.wcu.edu/.

3. A striking example is Lola Akande's novel What it Takes, a semi-autobiographical account of the life of a PhD student at a Nigerian university.

4. See https://www.blackcantabs.org/ for more information about the organization as well as their activities.

5. Pamela Roberts' book Black Oxford documents a number of these cases, and to her list one might add other examples, including the case of Okot p'Bitek, whose "failed" thesis challenged the disciplinary requirements. For a history, see Allen 2019.

6. See, for example, the volume edited by Rachel Johnson, the sister of the current Prime Minister of the UK (which includes an article by him), called The Oxford Myth. A reverence for all the pomp and ceremony of Oxford University permeates the volume, the cover of which shows a nostalgically rendered (but virtually unchanged) Oxford of previous decades.

7. See this BBC News article in which Louise Richardson, Vice Chancellor of Oxford University, is quoted https://www.bbc.co.uk/news/education-52999319.

8. In 2014 a celebration of Stuart Hall's legacies took place at TORCH, the Oxford Research Centre in the Humanities (see https://www.torch.ox.ac.uk/event/ stuart-hall-a-celebration). The Stuart Hall Foundation, in collaboration with Merton College, awards a studentship which is funded through Merton College and the Clarendon Fund, and is supported by TORCH. The studentship is intended to support the Foundation's vision to encourage scholars, artists, and researchers to build on Professor Stuart Hall's legacy. For more information, see http:/ / stuarthallfoundation.org/news/stuart-hall-doctoral-studentship-in-asso ciation-with-merton-college-and-torch-2019-2022/.

9. Ironically, the Stuart Hall studentship specifies that "the award covers course fees at the Home / EU rate," which means that any student from outside the UK would not be able to take it up, as it would not cover their fees.

10. The Codrington Library has recently been renamed "The Library at All Souls College," in acknowledgment of the fact that Codrington, after whom the library was named, had been a slaver and thus ought not to be commemorated.

11. https://cherwell.org/2016/06/20/student-protests-against-all-souls-codring ton/.

12. For a discussion of similar acts of repetition and rupture during the South African \#RhodesMustFall movements, see my monograph Written Under the Skin: Blood and Intergenerational Memory in South Africa. (Coetzee 2019). 